\title{
Pub-Med-dot-com, here we come!
}

\section{OPEN}

Stefan M. Pulst, MD, Dr med

Correspondence to Dr. Pulst: stefan.pulst@hsc.utah.edu

Neurol Genet

2016;2:e91; doi: 10.1212/ NXG.0000000000000091
As of April 8, 2016, articles in Neurology ${ }^{\circledR}$ Genetics can be searched using PubMed. Launched in 1996, PubMed is a search engine that accesses citations and abstracts of more than 26 million articles. Its primary sources include the MEDLINE database, which was started in the 1960s, and biomedical and life sciences journal articles that date back to 1946. In addition, PubMed accesses other sources, for example, citations to those life sciences journals that submit full-text articles to PubMed Central (PMC). PubMed Central was launched in 2000 as a free archive of biomedical and life science journals.

To be listed in PMC, a journal has to meet specific scientific and technical standards. These include a review of the scientific quality of published manuscripts and editorial team, as well as an assessment of the technical quality of the digital files. The decision regarding acceptance is based on published criteria and expert consultation. The editorial staff and Associate Editors of Neurology: Genetics deserve my thanks for achieving this milestone in the shortest possible time.

As of June 10, 2016, there are 80 articles listed in PubMed that can be found using the search term "Neurol Genet" [Journal]. All authors and editorialists who contributed to the first 7 issues can rest assured that electronic searches will lead investigators to their contributions. Our eighth issue adds 2 editorials, 4 full-length articles, and 4 Clinical/Scientific Notes.

Harris and colleagues ${ }^{1}$ describe a large multicenter observational study of patients with dysferlinopathy. They found significant clinical variability that was not explained by the type of mutation or steady-state levels of dysferlin. The results are further discussed by Wicklund ${ }^{2}$ in an accompanying editorial.

There is a well-known decline of specific serum lipids in the time preceding intracranial hemorrhage. Phuah and collaborators ${ }^{3}$ examine the effect of $A P O E$ alleles on this phenomenon. Carriers of an ApoE4 allele had a greater decline in lipids prior to
ICH. This effect was specific to total cholesterol and low-density lipoproteins.

Chan et $\mathrm{al}^{4}{ }^{4}$ used a novel approach to examine shared genetic risks for Alzheimer and Parkinson disease. They found that genetic variants increasing risk for Parkinson disease had an effect on $\mathrm{AD}$-associated protein levels in peripheral blood monocytes. The strongest association was found for a variant in the RIT2 locus.

George and friends ${ }^{5}$ examined the effect of common genetic variants on disease severity in patients with multiple sclerosis. Despite combining several large data sets and several analysis methods, no genetic variant rose to a prespecified significance level. An editorial by Kantarci ${ }^{6}$ further elucidates the implications of this study.

\section{STUDY FUNDING}

No targeted funding reported.

\section{DISCLOSURE}

Stefan M. Pulst has served on the editorial boards of Journal of Cerebellum, NeuroMolecular Medicine, Continuum, Experimental Neurology, Neurogenetics, and Nature Clinical Practice Neurology and as Editor-in-Chief of Current Genomics. Dr. Pulst conducts research supported by the NIH, Target ALS, and the National Ataxia Foundation. He has consulted for Ataxion Therapeutics, has received research funding from ISIS Pharmaceuticals, has served on a speakers' bureau for Athena Diagnostics, Inc., and is a stockholder of Progenitor Life Sciences. He has received license fee payments from Cedars-Sinai Medical Center, and has given expert testimony for Hall \& Evans, LLC. Dr. Pulst has received publishing royalties from Churchill Livingston (The Ataxias), AAN Press (Genetics in Neurology and Molecular Genetic Testing in Neurology, 2nd-5th editions), Academic Press (Genetics of Movement Disorders), and Oxford University Press (Neurogenetics). Dr. Pulst holds patents for Nucleic acids encoding ataxin-2-binding proteins, Nucleic acid encoding Schwannominbinding proteins and products related thereto, Transgenic mouse expressing a polynucleotide encoding a human ataxin-2 polypeptide, Methods of detecting spinocerebellar ataxia-2 nucleic acids, Nucleic acid encoding spinocerebellar ataxia- 2 and products related thereto, Schwannomin-binding proteins, and Compositions and methods for spinocerebellar ataxia. He receives an honorarium from the AAN as the Editor of Neurology: Genetics. Go to Neurology.org/ng for full disclosure forms.

\section{REFERENCES}

1. Harris E, Bladen CL, Mayhew A, et al. The Clinical Outcome Study for dysferlinopathy: an international multicenter study. Neurol Genet 2016;2:e89. doi: 10.1212/NXG. 0000000000000089 .

From the Department of Neurology, University of Utah, Salt Lake City.

This is an open access article distributed under the terms of the Creative Commons Attribution-NonCommercial-NoDerivatives License 4.0 (CC BY-NC-ND), which permits downloading and sharing the work provided it is properly cited. The work cannot be changed in any way or used commercially. 
2. Wicklund MP. Rare disease clinical trials: power in numbers. Neurol Genet 2016;2:e92. doi: 10.1212/NXG. 0000000000000092 . Editorial.

3. Phuah CL, Raffeld MR, Ayres AM, et al. APOE polymorphisms influence longitudinal lipid trends preceding intracerebral hemorrhage. Neurol Genet 2016;2:e81. doi: 10. 1212/NXG.0000000000000081.

4. Chan G, White CC, Winn PA, et al. Trans-pQTL study identifies immune crosstalk between Parkinson and
Alzheimer loci. Neurol Genet 2016;2:e90. doi: 10.1212/ NXG.0000000000000090.

5. George MF, Briggs FBS, Shao X, et al. Multiple sclerosis risk loci and disease severity in 7,125 individuals from 10 studies. Neurol Genet 2015;2:e87. doi: 10.1212/NXG. 0000000000000087.

6. Kantarci $\mathrm{OH}$. A new dawn for genetic association studies in multiple sclerosis. Neurol Genet 2016;2:e93. doi: 10.1212/ NXG.0000000000000093. Editorial. 


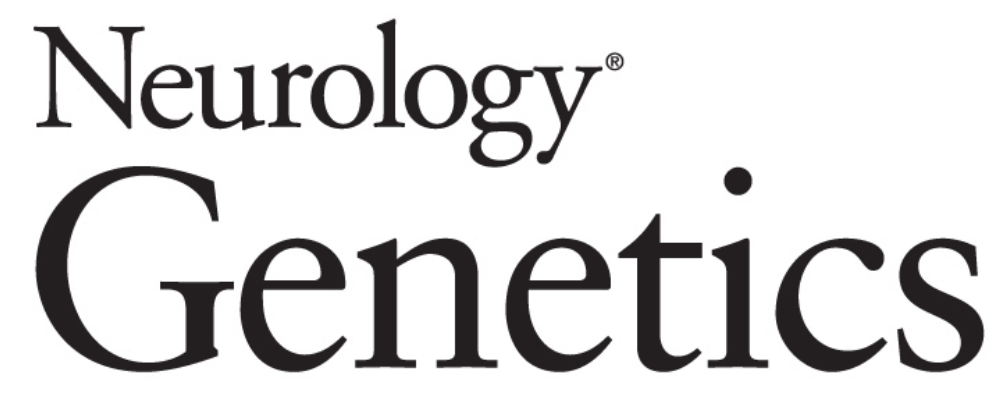

Pub-Med-dot-com, here we come!

Stefan M. Pulst

Neurol Genet 2016;2;

DOI 10.1212/NXG.0000000000000091

This information is current as of August 18, 2016

\section{Updated Information \&} Services

\section{References}

Subspecialty Collections

Permissions \& Licensing

Reprints including high resolution figures, can be found at: http://ng.neurology.org/content/2/4/e91.full.html

This article cites 6 articles, 5 of which you can access for free at: http://ng.neurology.org/content/2/4/e91.full.html\#\#ref-list-1

This article, along with others on similar topics, appears in the following collection(s):

\section{All Genetics}

http://ng.neurology.org//cgi/collection/all_genetics

Information about reproducing this article in parts (figures,tables) or in its entirety can be found online at:

http://ng.neurology.org/misc/about.xhtml\#permissions

Information about ordering reprints can be found online: http://ng.neurology.org/misc/addir.xhtml\#reprintsus

Neurol Genet is an official journal of the American Academy of Neurology. Published since April 2015, it is an open-access, online-only, continuous publication journal. Copyright ( 2016 American Academy of Neurology. All rights reserved. Online ISSN: 2376-7839.

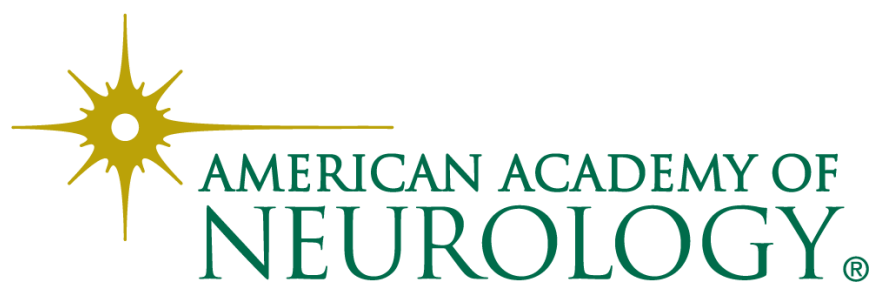

